\title{
KESESUAIAN DOKUMEN PERENCANAAN PENGADAAN TANAH BENDUNGAN KARIAN DENGAN UU PENGADAAN TANAH DI KABUPATEN LEBAK
}

\author{
Febri Yudhanto ${ }^{1 *}$, Priyo Katon Prasetyo ${ }^{2}$, Sudibyanung ${ }^{2}$ \\ ${ }^{1}$ Kantor Wilayah BPN Provinsi Jambi \\ Jl. Letjen MT Haryono, Pematang Sulur, Kec. Telanaipura, Kota Jambi, Jambi 36361 \\ ${ }^{2}$ Sekolah Tinggi Pertanahan Nasional \\ Jl. Tata Bumi No. 5 Banyuraden, Sleman, Yogyakarta \\ $1^{1 *}$ Corresponding author: febriyudhanto@gmail.com
}

\author{
Vol 1, No. 1 \\ April 2021 \\ Received \\ April 27 2021 \\ Accepted \\ May $26^{\text {th }} 2021$
}

\begin{abstract}
Land Acquisition Law Article 15 Paragraph (1) of Law Number 2 of 2012 concerning Land Acquisition for Development in the Public Interest regulates the Land Acquisition Planning Document (DPPT) which at least contains the purpose and objectives of the development plan, conformity with the the spatial plan and National and Regional Development Plans, land layout, land area needed, general description of land status, estimated time of land acquisition, estimated time of construction, estimated land value and budgeting plan. DPPT documents became the basic of Land Acquisition for location determination and anvancing process. Karian Land Aqcuisition is taken as an case study in this research. Karian Dam whose land acquisition began in 2007, until 2020 land acquisition has not yet been completed. Government regulations Number 37 Year 2010 regulating about dams will also be used as material for evaluations. DPPT Karian Dam was compiled in 2016. The purpose of this study was to evaluate the suitability of the 2016 Karian Dam (DPPT) with 73 Criteria for Land Acquisition and Government Regulations. This research uses a qualitative research method with a descriptive approach. The results of this study 14 criteria are suitable and 59 criteria are not suitable. With dominant points that are not appropriate, namely: (a) General Description of Land Status, (b) Estimated Time of Land Acquisition, (c) Estimated Time of Development Implementation; (d) Estimated Land Value, (e) Budgeting Plan.

Keywords: Land Acquisition, Conformity, Dams, Evaluations.
\end{abstract}

\section{INTISARI}

Pasal 15 Ayat (1) Undang-Undang Nomor 2 Tahun 2012 tentang Pengadaan Tanah Bagi Pembangunan Untuk Kepentingan Umum mengatur tentang Dokumen Perencanaan Pengadaan Tanah (DPPT) yang paling sedikit memuat maksud dan tujuan rencana pembangunan, kesesuaian dengan RTRW dan Rencana Pembangunan Nasional dan Daerah, letak tanah, luas tanah yang dibutuhkan, gambaran umum status tanah, perkiraan waktu pelaksanaan pengadaan tanah, perkiraan jangka waktu pelaksanaan pembangunan, perkiraan nilai tanah dan rencana penganggaran. DPPT tersebut yang akan menjadi dasar bagi pelaksanaan Penetapan Lokasi dan proses lanjutan pengadaan tanah. Sebagai studi kasus maka diambil pelaksanaan pengadaan tanah Bendungan Karian. Bendungan Karian yang pengadaan tanahnya dimulai dari tahun 2007, sampai dengan tahun 2020 belum dapat diselesaikan pengadaan tanahnya. PP Nomor 37 Tahun 2010 mengatur tentang Bendungan akan digunakan sebagai bahan untuk melakukan evaluasi. DPPT Bendungan Karian disusun pada tahun 2016. Tujuan dari penelitian ini adalah mengevaluasi Kesesuaian DPPT Bendungan Karian Tahun 2016 dengan 73 Kriteria Peraturan Perundang- Undangan Pengadaan Tanah dan PP tentang Bendungan. Penelitian ini menggunakan metode penelitian kualitatif dengan pendekatan dekriptif. Hasil dari penelitian ini 14 kriteria sesuai dan 59 kriteria tidak sesuai. Dengan poin dominan yang tidak sesuai yaitu: (a) Gambaran Umum Status Tanah, (b) Perkiraan Waktu Pelaksanaan Pengadaan Tanah, (c) Perkiraan Waktu Pelaksanaan Pembangunan; (d) Perkiraan Nilai Tanah, (e) Rencana Penganggaran. Kata Kunci: Pengadaan Tanah, Kesesuaian, Bendungan, Evaluasi. 


\section{A. Pendahuluan}

Setiap pembangunan selalu memerlukan tanah. Faktanya, pembangunan sering terhalang oleh ketersediaan tanah. Sitorus dan Limbong (2004) menyebutkan bahwa ketersediaan tanah negara yang "bebas" yaitu yang sama sekali tidak dihaki atau diduduki seseorang atau pihak-pihak berkepentingan sangat terbatas. Tanah di Indonesia umumnya sudah dipunyai atau setidaknya sudah ada yang menduduki. Akibatnya, apabila ada kegiatan pembangunan yang membutuhkan tanah maka tanah diperoleh melalui kegiatan pengadaan tanah.

Menurut Pasal 1 butir (2) Undang-Undang Nomor 2 Tahun 2012 tentang Pengadaan Tanah Bagi Pembangunan Untuk Kepentingan Umum yang selanjutnya disebut UU Nomor 2 Tahun 2012, Pengadaan Tanah adalah kegiatan menyediakan tanah dengan cara memberi ganti kerugian yang layak dan adil kepada pihak yang berhak. Tahapan dalam kegiatan pengadaan tanah terdiri dari tahapan perencanaan, tahapan persiapan, tahapan pelaksanaan dan tahapan penyerahan hasil.

Menurut Maria S.W. Sumardjono (2015), tahapan awal dan paling krusial dalam pengadaan tanah adalah tahapan perencanaan. Kegagalan dalam melewati proses tahapan ini akan berpotensi menghambat waktu penyelesaian pengadaan tanah. Berbagai masalah kemudian muncul di lapangan sebagai akibat dari dokumen perencanaan yang disusun belum sesuai dengan standar yang telah ada. Permasalahan ini tentu akan berpengaruh terhadap kegiatan-kegiatan selanjutnya dalam proses pengadaan tanah. Hal ini dapat disebabkan dari ketidaktahuan instansi yang memerlukan tanah dalam menyusun dokumen perencanaanya (Musleh yang dikutip dalam Budhiawan dkk. 2018, 60; Dewi \& Salim, 2020). Apa yang sudah ditulis dalam dokumen perencanaan terkadang tidak relevan dengan pelaksanaan, sehingga dalam pelaksanaan harus merevisi beberapa poin dalam dokumen perencanaan itu. Sejalan dengan itu pendapat Darmawan (2018) dalam (Budhiawan dkk. 2018, 60) apabila Badan Pertanahan Nasional (BPN) dimasukkan tim pemrosesan akhir (TPA) di Jawa Timur yaitu TPA Benowo dan TPA yang berada di Kabupaten Sidoarjo dalam perencanaan dapat memberikan masukan berupa data, baik data subyek, obyek bidang tanah yang akan terkena kegiatan pengadaan tanah. Hasil penelitian oleh Budhiawan dkk (2018) menyatakan bahwa kualitas Dokumen Perencanaan Pengadaan Tanah (DPPT) untuk tempat mempunyai kualitas data dalam dokumen perencanaan kurang baik, sehingga menyebabkan pekerjaan selanjutnya tidak berjalan dengan lancar.

Komite Percepatan Penyediaan Infrastruktur Prioritas (KPIPP) pada tahun 2019 dalam halaman websitenya menyebutkan bahwa salah satu contoh pengadaan tanah yang menjadi Proyek Strategis Nasional yang selanjutnya disebut PSN adalah pembangunan Bendungan Karian di Kabupaten Lebak. Rencana pembangunan Bendungan Karian di Kabupaten Lebak sudah dimulai dari tahun 2007, dan sampai dengan saat ini masih terkendala dengan masalah pembebasan lahannya (Kabar Banten 2018). Bendungan Karian yang ditargetkan selesai pada tahun 2020 dan akan berfungsi sebagai sumber penyedia air baku untuk Kabupaten Lebak, Kabupaten Tangerang, Kota Tangerang, Kota Tangerang Selatan dan wilayah DKI Jakarta sebesar 9,1 M3/detik, mengendalikan banjir, memproduksi listrik melalui Pembangkit 
Tenaga Minihidro sebesar 1,8 Megawatt yang akan mengaliri listrik bagi 10.000 kepala keluarga yang berada di 40 desa di sekitar Bendungan Karian serta dapat dimanfaatkan untuk meningkatkan pasokan air bagi lahan pertanian seluas 22.000 hektare di Provinsi Banten (KPIPP 2019).

Pembangunan Bendungan Karian sebagai salah satu Proyek Strategis Nasional disingkat PSN di Kabupaten Lebak membutuhkan lahan setidaknya seluas 2.226 hektare dengan daya tampung air mencapai 314,7 juta M3, dan kapasitas efektif sebesar 207,5 juta M3. Dengan luas yang sedemikian, Bendungan Karian selanjutnya akan menjadi bendungan terbesar ketiga setelah Bendungan Jatiluhur dan Bendungan Jatigede (KPPIP 2019). Untuk itu peneliti dalam tulisan ini akan menuangkan hasil penelitian mengenai kesesuaian DPPT Bendungan Karian yang disusun pada Tahun 2016 dengan peraturan perundang-undangan dalam kegiatan pengadaan tanah dan bendungan.

\section{B. Metode Penelitian}

Pada penelitian ini peneliti menggunakan metode kualitatif dengan pendekatan deskriptif. 73 Poin evaluasi ideal yang harus ada di dalam DPPT didapatkan dari UU Nomor 2 Tahun 2012 dengan aturan pelaksanaanya dan PP Nomor 37 Tahun 2010 yang digunakan untuk melakukan evaluasi kesesuaian DPPT Bendungan Karian Tahun 2016. Data yang didapatkan dalam penelitian ini adalah salinan DPPT Bendungan Karian Tahun 2016 dari Kantor Pertanahan Kabupaten Lebak. Teknik pengumpulan data berupa wawancara dengan PPK dan pelaksana Pengadaan Tanah Bendungan Karian dari BBWSC-3, Pelaksana pengadaan tanah Bendungan Karian dari Kantor Pertanahan Kabupaten Lebak dan studi dokumen dalam penelitian ini dilakukan dengan mempelajari bahan hukum primer dan studi dokumen pengadaan tanah Bendungan Karian yaitu DPPT Tahun 2016, SK Penetapan Lokasi Bendungan Karian. Tujuan dari penelitian ini adalah untuk mengetahui pihak yang terlibat, menyusun kriteria untuk mengevaluasi DPPT Bendungan Karian Tahun 2016, dan mengevaluasi kesesuaian DPPT Bendungan Karian Tahun 2016 dengan peraturan UU Pengadaan Tanah dan PP tentang Bendungan.

\section{Hasil dan Pembahasan}

Evaluasi Kesesuaian Dokumen Perencanaan Pengadaan Tanah di Bendungan

\section{Karian Kabupaten Lebak}

\section{Instansi Yang Terlibat Dalam Penyusunan DPPT Bendungan Karian Tahun 2016}

Pembangunan Bendungan Karian direncanakan oleh Instansi yang memerlukan tanah yaitu Balai Besar Wilayah Sungai Cidanau-Ciujung-Cidurian (BBWSC-3) yang pengadaan tanahnya dimulai dari tahun 2007 sampai dengan Tahun 2020 masih terus berjalan dengan capaian pembebasan lahannya mencapai 45,29\% dari target luas tanah $\pm 2.188 \mathrm{Ha}$. Data ini didapatkan dari wawancara dengan PPK Pengadaan Tanah Bendungan Karian Ibu Revita Kartikasari dan pelaksana pengadaan tanah dari BBWSC-3 Arwan Mega Susila menggunakan aplikasi on line zoom dapat dilihat pada Gambar 1. di bawah ini: 


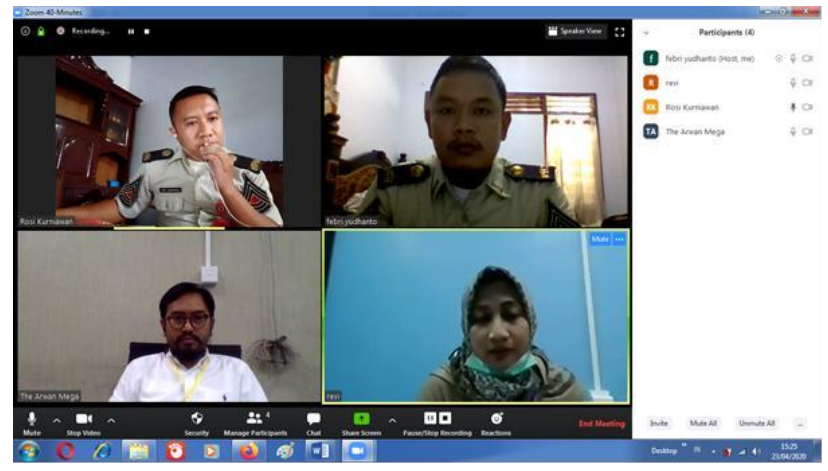

Gambar 1. Tangkapan layar wawancara dengan PPK dan Pelaksana Pengadaan Tanah Bendungan Karian dari BBWSC-3 Sumber: Dokumentasi Peneliti, 2020

Dalam wawancara dengan PPK Bendungan Karian juga didapatkan informasi bahwa DPPT Bendungan Karian Tahun 2016 disusun dengan melibatkan beberapa Instansi terkait diantaranya: Balai Besar Wilayah Sungai Cidanau-Ciujung-Cidurian (BBWSC-3) sebagai Instansi yang memerlukan tanah; Kantor Pertanahan Kabupaten Lebak sebatas dalam pembuatan peta rencana lokasi untuk pembangunan Bendungan Karian; Badan Perencana Pembangunan Daerah (BAPPEDA) Provinsi Banten sebatas mengenai rekomendasi untuk kesesuaian Rencana Tata Ruang Wilayah; Dinas Lingkungan Hidup dan Kehutanan (DLHK) Provinsi Banten terkait ijin lingkungan; Badan Lingkungan Hidup Daerah (BLHD) Provinsi Banten; Satuan Pemerintah tingkat Kecamatan Rangkasbitung, Maja, Sajira, Cimarga (terkait mekanisme penentuan harga pasar) dan nilai transaksi terakhir sebagai acuan dalam rencana penganggaran dalam pengadaan tanah untuk pembangunan Bendungan Karian; Pemerintah Desa Pasirtanjung, Sindangmulya, Sajira, Sukajaya, Pajagan, Mekarsari, Calungbungur, Bungurmekar, Sukarame, Sindangsari, Tambak lokasi yang terkena pembangunan Bendungan Karian.

\section{Kriteria Evaluasi Kesesuaian Dokumen Perencanaan menurut Ketentuan Peraturan Perundang-Undangan}

Evaluasi dilakukan antara DPPT untuk pembangunan Bendungan Karian Nomor: 02/DOK-PRC-TANAH/SNVT-PBK/BBWSC-3/2016 tanggal 21 Januari 2016 dengan kriteria evaluasi yang ada di dalam Undang-Undang Nomor 2 Tahun 2012, Perpres Nomor 71 Tahun 2012 yang beberapa kali dirubah dengan Perpres Nomor 40 Tahun 2014 tentang Perubahan Pertama, Perpres Nomor 99 Tahun 2014 tentang Perubahan Kedua, Perpres Nomor 30 Tahun 2015 tentang Perubahan Ketiga dan Perpres Nomor 148 Tahun 2015 tentang Perubahan Keempat atas Perpres Nomor 71 Tahun 2012 tentang Penyelenggaraan Pengadaan Tanah Bagi Pembangunan Untuk Kepentingan Umum dan PP Nomor 37 Tahun 2010 tentang Bendungan.

a. Kriteria evaluasi berdasarkan UU Nomor 2 Tahun 2012 dan Aturan Pelaksanaannya yaitu:

1) Maksud dan tujuan rencana pembangunan menguraikan: maksud dan rencana pembangunan Bendungan secara detail/rinci; menguraikan tujuan rencana pembangunan Bendungan Karian secara detail/ rinci. 
2) Kesesuaian dengan Rencana Tata Ruang Wilayah (RTRW) dan Prioritas Pembangunan memuat: Kesesuaian dengan RTRW Nasional; Kesesuaian dengan RTRW Provinsi Banten; Rencana Pembangunan Jangka Menengah Provinsi Banten; Rencana Strategis; Rencana Kerja Pemerintah Instansi BBWS CidanauCiujung-Cidurian.

3) Letak tanah memuat: Kesesuaian letak obyek pengadaan tanah nama desa/ kelurahan dan jumlahnya; kesesuaian letak obyek pengadaan tanah berupa kecamatan dan jumlahnya; kesesuaian letak obyek pengadaan tanah di Kabupaten Lebak; kesesuaian letak obyek pengadaan tanah di Provinsi Banten.

4) Luas tanah yang dibutuhkan memuat luas tanah perkiraan yang dibutuhkan dalam proses pengadaan tanah untuk Pembangunan Bendungan Karian.

5) Gambaran umum status tanah memuat: Data awal penguasaan atas tanah pada lokasi pengadaan tanah untuk pembangunan Bendungan Karian dan data awal pemilikan atas tanah pada lokasi pengadaan tanah untuk pembangunan Bendungan Karian.

6) Perkiraan jangka waktu pelaksanaan pengadaan tanah memuat: Perkiraan jangka waktu pelaksanaan tahap perencanaan; perkiraan jangka waktu pelaksanaan tahap persiapan; perkiraan jangka waktu tahap pelaksanaan; perkiraan jangka waktu tahap penyerahan hasil.

7) Perkiraan jangka waktu pelaksanaan pembangunan memuat perkiraan jangka waktu pelaksanaan pembangunan Bendungan Karian.

8) Perkiraan nilai tanah memuat: kesesuaian perkiraan nilai Ganti Kerugian Obyek pengadaan tanah berupa tanah; kesesuaian perkiraan nilai ruang, bangunan, tanaman, benda yang berkaitan dengan tanah.; kesesuaian perkiraan nilai kerugian lain yang dapat dinilai.

9) Rencana penganggaran menguraikan: besaran dana pengadaan tanah; sumber dana pengadaan tanah; rincian alokasi dana untuk perencanaan; menguraikan rincian alokasi dana untuk persiapan; menguraikan rincian alokasi dana untuk pelaksanaan; menguraikan rincian alokasi dana untuk penyerahan hasil; menguraikan rincian alokasi dana untuk administrasi dan pengelolaan; menguraikan rincian alokasi dana untuk sosialisasi.

10) Studi Kelayakan menguraikan: hasil survei sosial ekonomi; menguraikan kelayakan lokasi; menguraikan analisis biaya dan manfaat pembangunan bagi wilayah dan masyarakat; menguraikan perkiraan nilai tanah; menguraikan analisis mengenai dampak lingkungan hidup dan AMDAL; DPPT ditetapkan oleh pimpinan instansi yg memerlukan tanah; perencanaan melibatkan pengampu dan pemangku kepentingan.

b. Kriteria evaluasi berdasarkan PP Nomor 37 Tahun 2010 Tentang Bendungan. Dokumen teknis dalam rangka pembangunan Bendungan Karian seharusnya memuat tahapan dan kegiatan berikut:

1) Tahapan Persiapan Pembangunan Bendungan menguraikan dan memuat: rencana pengelolaan SDA pada wilayah sungai dengan pembangunan bendungan; kondisi Sumber Daya Air (SDA) \& rencana tata ruang untuk pembangunan; izin penggunaan SDA sesuai kewenangannya paling lama 5 
(lima) Tahun; identitas pembangun bendungan; rekomendasi teknis dari Unit Pelaksana Teknis yang membidangi SDA; studi kelayakan dan dokumen pengelolaan lingkungan hidup; tahapan perencanaan pembangunan.

2) Tahapan Perencanaan Pembangunan Bendungan menguraikan dan memuat: analisis kondisi topografi berupa rencana tapak bendungan, jalan akses, penyimpanan material, tempat pembuangan galian, dan daerah genangan serta quarry dan borrow area; analisis geologi; analisis hidrologi daerah tangkapan air; analisis kependudukan di daerah tapak bendungan dan rencana genangan serta daerah penerima manfaat bendungan; analisis sosial, ekonomi dan budaya pada daerah tapak bendungan dan rencana genangan serta penerima manfaat bendungan; analisis kelayakan teknis, ekonomis, umur layanan dan lingkungan untuk setiap alternatif rencana bendungan; rencana bendungan yang paling layak dipilih dan desain pendahuluan bendungan serta rencana penggunaan sumber daya air; gambar teknis rencana bendungan, bangunan pelengkap, fasilitas operasi dan pemeliharaan; nota desain yang meliputi kriteria yang dipergunakan dalam menyusun desain dan perhitungan gambar teknis; spesifikasi teknis untuk mencapai kualitas yang disyaratkan; metoda pelaksanaan, cara pengelakan sungai dan penimbunan tubuh bendungan; rencana anggaran biaya pelaksanaan konstruksi bendungan; lokasi tanah yang diperlukan; peta dan luasan tanah; status dan kondisi tanah; rencana pembiayaan; dilengkapi dengan studi pemukiman kembali (untuk permukiman).

3) Tahapan Persiapan Pelaksanaan Konstruksi Pembangunan Bendungan menguraikan dan memuat: dokumen permohonan izin pelaksanaan konstruksi; dokumen desain yang telah disetujui, studi pengadaan tanah dan pengelolaan lingkungan; dilakukan sesuai hasil studi pengadaan tanah; dilakukan sesuai ketentuan peraturan-perundang-undangan; mengutamakan teknologi; memanfaatkan sumber daya lokal.

4) Tahapan Pengisian Awal Waduk Pembangunan Bendungan: menguraikan permohonan pengisian awal waduk; pembentukan unit pengelola bendungan; laporan akhir pelaksanaan konstruksi; laporan penyiapan pelaksanaan daerah genangan waduk; rencana pengelolaan bendungan; rencana tindak darurat.

\section{Evaluasi Kesesuaian DPPT Tahun 2016 untuk pembangunan Bendungan Karian}

a. Maksud dan Tujuan Rencana Pembangunan Bendungan Karian:

1) Maksud dari rencana Pembangunan Bendungan Karian yang dimuat dalam DPPT Bendungan Karian Tahun 2016 merupakan kebijakan strategis nasional yang berfungsi antara lain sebagai pengendali bencana banjir, penyediaan air baku bagi kepentingan irigasi, rumah tangga dan industri. Maksud dalam peraturan perundang-undangan menguraikan gambaran secara umum yang ingin dicapai dari rencana pembangunan kepentingan umum sehingga dalam hal ini, maksud dari rencana pembangunan Bendungan Karian di dalam DPPT ini sudah diuraikan sesuai dan memuat jelas sesuai dengan peraturan.

2) Tujuan menurut peraturan perundang-undangan dalam kegiatan pengadaan tanah menguraikan hal- hal spesifik yang akan dicapai untuk dapat mewujudkan maksud dari rencana pembangunan untuk kepentingan umum dan berisi manfaat 
yang akan diperoleh oleh masyarakat umum dari rencana pembangunan itu. Dalam tujuan dari pembangunan Bendungan Karian, Kabupaten Lebak tidak disebutkan untuk memperoleh manfaat dari adanya pembangunan Bendungan Karian dan hanya untuk perkotaan. Kabupaten Lebak sebagai lokasi pembangunan Bendungan Karian seharusnya menjadi prioritas utama dan penerima manfaat dari adanya Pembangunan Bendungan Karian ini. Sehingga hasil evaluasinya adalah tidak sesuai dengan peraturan perundang-undangan

b. Kesesuaian dengan Rencana Tata Ruang Wilayah (RTRW), Rencana Pembangunan Nasional dan Daerah Bendungan Karian:

1) Kesesuaian dengan RTRWN Bendungan Karian yang dalam Lampiran VI PP Nomor 26 Tahun 2008 tanggal 10 Maret 2008 dalam Tabel Wilayah Sungai (WS) berada di dalam Kolom Nomor Urut 26, Kolom Wilayah Sungai (WS) Cidanau - Ciujung Cidurian - Cisadane-Ciliwung - Citarum- (I-IV/A/1) yang terletak di Kolom Provinsi Banten-DKI Jakarta- Jawa Barat, dan Kolom Keterangan Lintas Provinsi yang pola pengelolannya ditetapkan dengan Peraturan Menteri dan menjadi kewenangan Pemerintah Pusat, sehingga dalam hal ini Kesesuaian dengan RTRW Nasional sesuai dengan ketentuan peraturan perundang- undangan.

2) Terhadap kriteria evaluasi yang ditetapkan, pada poin kesesuaian dengan RTRW Provinsi Banten hal yang termuat di dalam DPPT Bendungan Karian Tahun 2016 telah sesuai dan ada (jelas) menguraikan mengenai substansi dan maknanya, karena sesuai dengan Perda Provinsi Banten Nomor 2 Tahun 2011 tentang Rencana Tata Ruang Wilayah Provinsi Banten Tahun 2010- 2030 dan peta pola RTRW Provinsi Banten Tahun 2010-2030 telah memuat Bendungan Karian merupakan kawasan strategis dari sudut kepentingan pendayagunaan sumber daya alam dan/atau teknologi tinggi (Pasal 65 Huruf (f) Perda Provinsi Banten Nomor 2 Tahun 2011). Sejalan dengan itu maka isi dari DPPT Bendungan Karian Tahun 2016 sesuai dengan RTRW Provinsi Banten.

3) RTRW Kabupaten Lebak Tahun 2014- 2034 tercantum di dalam Perda Kabupaten Lebak Nomor 2 Tahun 2014 yang di dalam Pasal 50 Huruf (a) Rencana pengembangan kawasan strategis dari sudut kepentingan pendayagunaan sumber daya alam dan teknologi tinggi sebagaimana dimaksud dalam Pasal 47 ayat (1) huruf c diarahkan dan meliputi Bendungan Karian, sehingga dapat ditarik kesimpulan bahwa Rencana Pembangunan Bendungan Karian di Kabupaten Lebak telah sesuai dengan RTRW Kabupaten Lebak.

4) Dalam DPPT Bendungan Karian Tahun 2016 disebutkan bahwa sebagaimana diamanatkan dalam Perda Nomor 1 Tahun 2010 tentang Rencana Pembangunan Jangka Panjang Daerah (RP.JPD) Provinsi Banten Tahun 2005-2025 bahwa Rencana Pembangunan Jangka Menengah Daerah 2012-2017 yang dimuat di dalam Perda Provinsi Banten Nomor 2 Tahun 2010 merupakan tahap akselerasi1 dengan fokus pembangunan diprioritaskan 7 lingkup yang salah satunya Berdasarkan prioritas pembangunan itu, rencana pembangunan Bendungan Karian termasuk ke dalam prioritas pembangunan jangka menengah daerah Provinsi Banten melalui: pemantapan kualitas pelayanan prasarana dan sarana wilayah. Dalam kriteria evaluasi pada poin ini DPPT Bendungan Karian telah 
sesuai dan memuat dengan rinci apa yang ada dalam peraturan perundangundangan.

5) Dalam uraian yang tercantum dalam DPPT Bendungan Karian Tahun 2016 menyebutkan bahwa berdasarkan Peraturan Menteri Pekerjaan Umum Nomor: 20/PRT/M/2012 tentang Rencana Strategis Kementerian Pekerjaan Umum Tahun 2010- 2014 pada lampiran 2.2 tentang Rencana Kegiatan Master Plan Percepatan dan Perluasan Pembangunan Ekonomi Indonesia (MP3EI) Tahun 2011- 2025 meliputi Penyediaan Infrastruktur Penyediaan Sumber Daya Air pada koridor Pulau Jawa:Pembangunan Bendungan Karian; pembangunan Water Convenyance Karian (10.000 liter/detik). Dari uraian tersebut isi dalam DPPT Bendungan Karian Tahun 2016 tentang isinya terhadap Rencana Strategis Kementerian Pekerjaan Umum telah sesuai dengan peraturan perundangundangan.

c. Kesesuaian Letak Tanah yang dibutuhkan untuk Pembangunan Bendungan Karian: Dalam DPPT Bendungan Karian Tahun 2016 berisi bahwa lokasi rencana pengadaan tanah untuk Pembangunan Bendungan Karian di Kabupaten Lebak Provinsi Banten terletak di 11 Desa, 4 Kecamatan, dengan rincian sebagai berikut: Lokasi tubuh bendungan dan bangunan pelengkapnya terletak di Desa Pasirtanjung Kecamatan Rangkasbitung, Desa Sindangmulya/Kecamatan Maja, Desa Sajira, Desa Sukajaya, Desa Pajagan, Desa Mekarsari, Desa Calungbungur, Desa Bungurmekar, Desa Sukarame, Desa Sindangsari/ Kecamatan Sajira, Desa Tambak/ Kecamatan Cimarga, Kabupaten Lebak Provinsi Banten.

Dalam Perpres Nomor 71 Tahun 2012 Pasal 5 Ayat (4), dijelaskan bahwa letak tanah menguraikan wilayah administrasi kelurahan/desa atau nama lain, kecamatan, kabupaten/ kota, dan provinsi tempat lokasi pembangunan yang direncanakan. Pada DPPT Bendungan Karian Tahun 2016 sudah diuraikan dimana mulai dari desa, kecamatan, kabupaten, dan provinsi lokasi rencana pembangunan Bendungan Karian secara rinci dan jelas, sehingga telah sesuai dengan peraturan perundang-undangan

d. Kesesuaian Luas Tanah yang Dibutuhkan untuk Rencana Pembangunan Bendungan Karian:

DPPT untuk pembangunan Bendungan Karian Tahun 2016 menguraikan luas tanah yang dibutuhkan untuk Rencana Pembangunan Bendungan Karian di Kabupaten Lebak- Provinsi Banten seluas $\pm 1.362,29$ ha dengan rincian sebagai berikut: luas tanah yang dibutuhkan untuk lokasi tubuh bendungan dan bangunan pelengkapnya seluas $\pm 4,99$ ha; luas tanah yang dibutuhkan untuk genangan waduk dan greenbelt seluas $\pm 1.357,30$ ha. Akan tetapi, total luas lahan yang dibutuhkan dalam DPPT Bendungan Karian Tahun 2016 belum memberikan gambaran luas dan jumlah bidang yang akan direncanakan terkena pengadaan Bendungan Karian.

Dalam Perpres Nomor 71 Tahun 2012 Pasal 5 Ayat (5) luas tanah yang dibutuhkan menguraikan perkiraan luas tanah yang dibutuhkan. Luas tanah dari DPPT Bendungan Karian Tahun 2016 bersumber dari dokumen LARAP 2008 dan 2009. 
Dalam DPPT Bendungan Karian Tahun 2016 ini juga belum menjelaskan berapa jumlah bidang dari setiap desa yang ada. Dari evaluasi terhadap kriteria ini diketahui bahwa kesesuaian luas tanah yang dibutuhkan dalam rencana pembangunan Bendungan Karian yang ada di dalam DPPT Bendungan Karian Tahun 2016 tidak sesuai dengan peraturan perundang-undangan.

e. Kesesuaian Gambaran umum status tanah dalam DPPT Bendungan Karian Tahun 2016:

Gambaran umum status tanah dalam DPPT Bendungan Karian Tahun 2016 menyatakan bahwa secara umum status tanah yang akan dibebaskan dibuktikan dengan Surat Keterangan dari Kepala Desa yang menerangkan status tanah sebagai data awal mengenai penguasaan dan alat bukti kepemilikan.

Gambaran umum status tanah dalam Perpres Nomor 71 Tahun 2012 menguraikan data awal penguasaan dan pemilikan atas tanah. DPPT Bendungan Karian Tahun 2016 tidak menguraikan gambaran umum status tanah dari 11 desa lokasi rencana pembangunan Bendungan Karian di Kabupaten Lebak dan juga tidak menguraikan secara rinci sisa bidang tanah yang telah di bebaskan dari pengadaan tanah yang dimulai sejak Tahun 2007 sampai dengan Tahun 2015.

Setelah dilakukan evaluasi terhadap kesesuaian gambaran umum status tanah yang tercantum dalam DPPT Bendungan Karian Tahun 2016 dengan peraturan perundang-undangan dalam kegiatan pengadaan tanah maka dalam poin ini hasilnya adalah tidak sesuai dengan peraturan perundang- undangan.

f. Kesesuaian Perkiraan Waktu Pelaksanaan Pengadaan Tanah DPPT Bendungan Karian Tahun 2016:

Dalam DPPT Bendungan Karian Tahun 2016 waktu pelaksanaan pengadaan tanah pada setiap tahap akan dilaksanakan dengan rincian dalam Tabel 1 di bawah ini.

Tabel 1. Perkiraan Waktu Pengadaan Tanah dalam DPPT Bendungan Karian Tahun 2016

\begin{tabular}{ccc}
\hline No & Tahapan Kegiatan & Waktu Pelaksanaan \\
\hline 1 & Perencanaan & 12 bulan \\
2 & Persiapan & 3 bulan \\
3 & Pelaksanaan & 22 bulan \\
4 & Serah Terima & 1 bulan \\
& Total Waktu Tahapan Kegiatan & 38 bulan \\
\hline
\end{tabular}

Sumber: DPPT Bendungan Karian, 2016

Pada Tabel 1. perkiraan waktu pelaksanaan pengadaan tanah yang tercantum dalam DPPT Bendungan Karian Tahun 2016 tahapan kegiatan perencanaan memerlukan waktu pelaksanaan 12 bulan, tahapan persiapan 3 bulan, tahapan pelaksanaan 22 bulan dan serah terima 1 bulan. Jangka waktu maksimal menurut UU Nomor 2 Tahun 2012, Perpres Nomor 71 Tahun 2012 dan Perpres Nomor 148 Tahun 2015 untuk masing- masing tahap kegiatan pengadaan tanah memerlukan waktu maksimal sebagai berikut: 
1) Tahap persiapan pengadaan tanah dengan total maksimal 260 hari kerja dan jika dikonversi dalam satuan bulan menjadi 13 bulan;

2) Tahap pelaksanaan pengadaan tanah dengan total maksimal 270 hari kerja dan jika dikonversi dalam satuan bulan adalah maksimal 13,5 bulan;

3) Tahap penyerahan hasil pengadaan tanah kepada instansi yang memerlukan tanah adalah maksimal 3 hari kerja;

4) Untuk kegiatan pendaftaran/ pensertifikatan yang diatur dalam Pasal 112 Ayat (4) Perpres Nomor 148 Tahun 2015 wajib dilakukan oleh Instansi yang memerlukan tanah dalam waktu paling lama 30 hari kerja sejak penyerahan hasil pengadaan tanah.

Dari uraian di atas setelah dilakukan evaluasi antara DPPT Bendungan Karian Tahun 2016 dengan ketentuan peraturan perundang-undangan dalam kegiatan pengadaan tanah maka:

1) Kesesuaian jangka waktu pelaksanaan tahap perencanaan yang tertulis di DPPT Tahun 2016 sesuai dengan peraturan perundang-undangan;

2) Kesesuaian jangka waktu pelaksanaan tahap persiapan yang tertulis di DPPT Bendungan Karian Tahun 2016 tidak sesuai dengan peraturan perundang-undangan;

3) Kesesuaian jangka waktu tahap pelaksanaan yang tertulis di DPPT Bendungan Karian Tahun 2016 tidak sesuai dengan peraturan perundangundangan;

4) Kesesuaian jangka waktu penyerahan hasil antara DPPT Bendungan Karian Tahun 2016 tidak sesuai dengan peraturan perundang- undangan.

g. Kesesuaian Perkiraan Jangka Waktu Pelaksanaan Pembangunan Bendungan Karian dalam DPPT Bendungan Karian Tahun 2016.

Jangka waktu pembangunan Bendungan Karian di dalam DPPT Bendungan Karian Tahun 2016 tertulis membutuhkan waktu pelaksanaan \pm 4 Tahun seperti ada pada Gambar 2 dibawah ini:

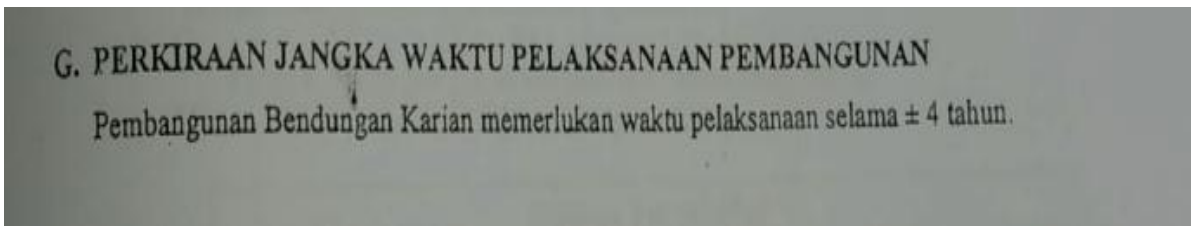

Gambar 2. Perkiraan Waktu Pelaksanaan Pembangunan Bendungan Karian Sumber: DPPT Bendungan Karian, 2016

Pasal 5 Ayat (8) Perpres Nomor 71 Tahun 2012 menyatakan bahwa perkiraan jangka waktu pelaksanaan pembangunan menguraikan perkiraan waktu yang diperlukan untuk melaksanakan pembangunan. Menurut Pasal 7 PP Nomor 37 Tahun 2010 tentang Bendungan, tahapan pelaksanaan pembangunan bendungan dilaksanakan meliputi tahap persiapan pembangunan, perencanaan pembangunan, perencanaan konstruksi, dan pengisian awal waduk. Masing- 
masing kegiatan dalam tahapan ini seharusnya diuraikan mengenai perkiraan waktu pelaksanaannya, sehingga dapat di total jumlah waktu yang dibutuhkan dalam pelaksanaan pembangunan Bendungan Karian. Pembuatan time schedule atau jadwal pelaksanaan pembangunan Bendungan dapat dibuat seperti contoh jadwal kegiatan dalam DPPT Pembangunan Jalan Tol Tebing Tinggi - Parapat Tahap I Ruas Tebing Tinggi- Pematang Siantar pada Gambar 3. di bawah ini.

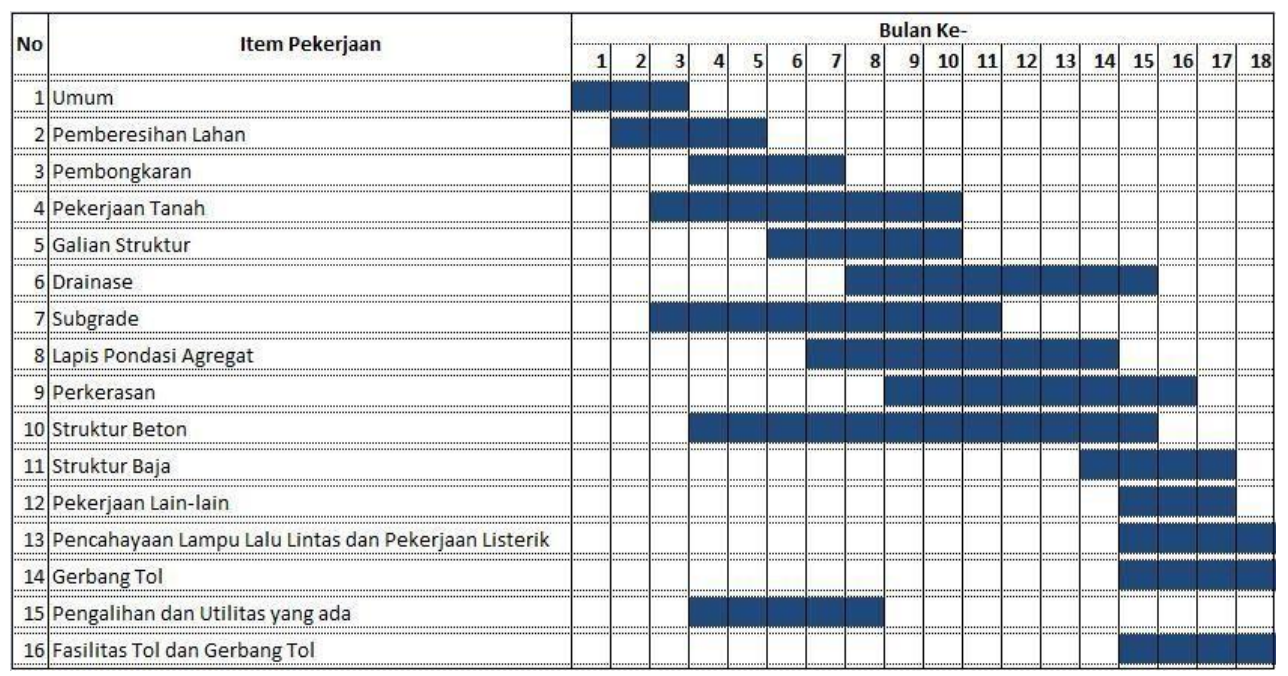

Gambar 3. Jadwal Pelaksanaan Konstruksi Jalan Tol Tebing Tinggi - Parapat Tahap I Ruas Tebing Tinggi - Pematang Siantar ( \pm 58.7 Km).

Sumber: DPPT Pembangunan Jalan Tol Tebing Tinggi - Parapat Tahap I Ruas Tebing TinggiPematang Siantar, 2018

Setelah dilakukan evaluasi terhadap kesesuaian DPPT Bendungan Karian Tahun 2016 mengenai jangka waktu pelaksanaan pembangunan Bendungan dengan peraturan perundang-undangan hasilnya tidak sesuai karena pada poin jangka waktu pelaksanan DPPT Bendungan Karian Tahun 2016 sama sekali tidak menguraikan jadwal kegiatan dan waktu spesifik untuk masing-masing kegiatan dalam perencanaan pembangunan Bendungan Karian.

h. Kesesuaian Perkiraan Nilai Tanah dalam DPPT Bendungan Karian Tahun 2016:

Perkiraan besarnya nilai ganti kerugian tanah dan bangunan dalam DPPT Bendungan Karian Tahun 2016 dilakukan dengan pendekatan harga yang ditetapkan pemerintah dan Nilai Jual Objek Pajak (NJOP). Sedangkan perkiraan biaya ganti rugi tanaman dan bangunan mengacu kepada (SSH) Belanja Daerah Kabupaten Lebak TA 2014.

DPPT Bendungan Karian Tahun 2016 dalam rencana perkiraan nilai ganti rugi tanah, tanaman, bangunan masih mengacu pada Dokumen LARAP Tahun 2008 dan 2009 dan hasil survei Tahun 2014 dan 2015 dan Standar Satuan Harga (SSH) belanja Daerah Kabupaten Lebak Tahun Anggaran 2014 dan belum disusun berdasarkan survei sosial ekonomi pada setiap desa. Padahal, dalam Pasal 34 Ayat (1) UU Nomor 2 Tahun 2012 menyatakan bahwa Nilai Ganti Kerugian yang dinilai oleh Penilai merupakan nilai pada saat pengumuman penetapan lokasi pembangunan Bendungan Karian Tahun 2016. Sehingga seharusnya estimasi perkiraan harga tanah, bangunan, dan tanaman mengacu pada nilai harga pada 
tahun 2016 karena Penetapan Lokasi yang menjadi acuan tahun penilaian adalah Tahun 2016. Setelah dilakukan evaluasi terhadap perkiraan nilai ganti kerugian baik ganti kerugian tanah, bangunan, serta tanam tumbuh di atasnya yang ada di dalam DPPT Bendungan Karian Tahun 2016 didapatkan hasil sebagai berikut:

a. Perkiraan nilai ganti kerugian pembebasan tanah untuk pembangunan Bendungan Karian tidak sesuai, karena nilai perkiraan untuk pembebasan tanah adalah nilai tanah pada Tahun 2016, karena di Tahun 2016 Penetapan Lokasi Bendungan Karian di tetapkan oleh Gubernur Banten;

b. Perkiraan nilai ganti rugi bangunan dalam rangka pembangunan Bendungan Karian tidak sesuai karena penetapan harga bangunan yang bersumber dari Standar Satuan Harga (SSH) belanja Daerah Kabupaten Lebak Tahun Anggaran 2014 tidak relevan untuk digunakan di Tahun 2016;

c. Perkiraan nilai ganti rugi tanaman dan tanam tumbuh di atas tanahnya dalam rangka pembangunan Bendungan Karian tidak sesuai. Sumber dari perencanaan nilai perkiraan tanaman adalah Standar Satuan Harga (SSH) belanja Daerah Kabupaten Lebak Tahun Anggaran 2014 sedangkan Penetapan Lokasi yang menjadi dasar penilaian Nilai Ganti Kerugian ditetapkan Tahun 2016. Selain itu, benda lain yang berkaitan dengan tanah misalnya tiang listrik, pipa gas bumi, pipa PDAM, pipa minyak tidak dicantumkan biaya/ besaran nilai ganti kerugian dalam DPPT Bendungan Karian Tahun 2016;

d. Kerugian lain yang dapat dinilai disini juga tidak diuraikan secara rinci, misalnya kerugian non fisik contohnya kerugian lainnya yang meliputi kerugian emosional (Solatium), kehilangan pekerjaan atau kehilangan bisnis termasuk alih profesi, kompensasi masa tunggu (Bunga), kerugian sisa tanah, kerusakan fisik lainnya (biaya pemindahan, biaya pengosongan) yang tidak diakomodir dalam poin ini. Sehingga dalam poin ini tidak sesuai dengan peraturan perundang-undangan

i. Rencana Penganggaran Pengadaan Tanah yang akan dilaksanakan pada TA. 2016 diuraikan pada rincian Tabel 2 di bawah ini.

Tabel 2. Uraian Rencana Penganggaran Pengadaan Tanah Untuk Pelaksanaan Pembangunan Bendungan Karian Untuk Tahun Anggaran 2016.

\begin{tabular}{cllr}
\hline No & Uraian & \multicolumn{2}{c}{ Rencana Anggaran } \\
\hline 1 & Biaya Perencanaan & $\mathrm{Rp}$ & 1.500 .000 .000 \\
2 & Biaya Persiapan & $\mathrm{Rp}$ & 500.000 .000 \\
3 & Biaya Pelaksanaan & $\mathrm{Rp}$ & 219.025 .419 .427 \\
4 & Biaya Penyerahan Hasil & $\mathrm{Rp}$ & 300.000 .000 \\
& Jumlah & $\mathrm{Rp}$ & 221.325 .419 .427 \\
\hline
\end{tabular}

Sumber: DPPT Bendungan Karian, 2016 
Pasal 5 Ayat (10) Perpres Nomor 71 Tahun 2012 menyatakan bahwa rencana penganggaran menguraikan besaran dana, sumber dana, dan rincian alokasi dana untuk perencanaan, persiapan, pelaksanaan, penyerahan hasil, administrasi dan pengelolaan, serta sosialisasi. Evaluasi pada masing- masing poin kriteria evaluasi adalah sebagai berikut:

1. Menguraikan besaran dana pengadaan tanah

DPPT Bendungan Karian Tahun 2016 memuat rincian besarnya rencana penganggaran pengadaan tanah dengan jumlah dari masing- masing tahap dalam kegiatan pengadaan tanah dan jumlah rencana penganggaran untuk Tahun Anggaran 2016- 2017 adalah Rp.622.808.634.458,-. Dengan demikian dalam kriteria ini sudah sesuai dengan peraturan perundang-undangan

2. Menguraikan sumber dana pengadaan tanah

Sumber dana pengadaan tanah Bendungan Karian dalam DPPT Tahun 2016 berasal dan dianggarkan dari DIPA Satuan Kerja Non Vertikal Tertentu (SNVT) Pembangunan Bendungan Karian. Sehingga dalam kriteria evaluasi ini DPPT Bendungan Karian Tahun 2016 telah sesuai.

3. Menguraikan rincian alokasi dana untuk perencanaan

DPPT Bendungan Karian Tahun 2016 hanya memuat biaya perencanaan dengan total biaya Rp.1.500.000.000,-. Rincian dan uraian kegiatan serta masing- masing penganggaran dalam tahap perencanaan tidak diuraikan secara rinci. Dalam Peraturan Peraturan Menteri Keuangan (PMK) Nomor 13 /PMK.02/2013 tentang Biaya Operasional dan Biaya Pendukung (BOPP) Penyelenggaraan Pengadaan Tanah Bagi Pembangunan Untuk Kepentingan Umum yang Bersumber dari Anggaran Pendapatan dan Belanja Negara Pasal 3 Ayat (1) BOPP digunakan untuk kegiatan tahapan perencanaan mulai dari huru (a) sampai dengan huruf (t) (PMK) Nomor 13 /PMK.02/2013. Setelah dilakukan evaluasi pada kriteria ini DPPT Bendungan Karian Tahun 2016 tidak sesuai dengan ketentuan peraturan perundang-undangan.

4. Menguraikan rincian alokasi dana untuk tahapan persiapan

DPPT Bendungan Karian Tahun 2016 hanya memuat biaya pada tahap persiapan dengan total biaya Rp. 500.000.000,-. Rincian dan uraian kegiatan serta masing- masing rencana penganggaran dalam tahap persiapan tidak diuraikan secara rinci, baik rencana kegiatan dalam tahap persiapan maupun rencana penganggaran. Tahap persiapan rincian kegiatan utama adalah seperti tercantum dalam Pasal 3 Ayat (2) huruf (a) sampai dengan huruf (j) PMK Nomor 13 /PMK.02/2013. Setelah dilakukan evaluasi pada kriteria ini DPPT Bendungan Karian Tahun 2016 tidak sesuai dengan ketentuan peraturan perundang-undangan.

5. Menguraikan rincian alokasi dana untuk tahapan pelaksanaan DPPT Bendungan Karian Tahun 2016 hanya memuat jumlah biaya pada tahap pelaksanaan yaitu Rp. 619.808.634.458,-- Uraian rencana kegiatan serta rencana penganggaran pada tahap pelaksanaan tidak diuraikan secara rinci. BOPP digunakan pada tahapan pelaksanaan dengan kegiatan seperti yang tercantum dalam Pasal 3 Ayat (3) huruf (a) sampai dengan huruf (I) PMK Nomor 13 /PMK.02/2013. Di luar dari biaya BOPP diatas dimasukkan juga 
total rencana penganggaran dari nilai Ganti Kerugian. Setelah dilakukan evaluasi pada kriteria ini DPPT Bendungan Karian Tahun 2016 tidak sesuai dengan ketentuan peraturan perundang-undangan.

6. Menguraikan rincian alokasi dana untuk kegiatan penyerahan hasil DPPT Bendungan Karian Tahun 2016 hanya memuat biaya pada tahap penyerahan hasil dengan rencana total biaya Rp. 1.000.000.000,-- Rincian, uraian kegiatan dan rencana penganggaran dalam tahap penyerahan hasil tidak diuraikan. Tahap penyerahan hasil rincian kegiatan utama adalah sebagai berikut sesuai Pasal 3 Ayat (4) huruf (a) sampai dengan huruf (c) PMK Nomor 13 /PMK.02/2013. Setelah dilakukan evaluasi dengan kriteria pada poin ini DPPT Bendungan Karian Tahun 2016 tidak sesuai dengan ketentuan peraturan perundang-undangan.

7. Menguraikan rincian alokasi dana untuk administrasi dan pengelolaan Dalam DPPT Bendungan Karian Tahun 2016 rincian alokasi dana untuk administrasi dan pengelolaan tidak diuraikan secara rinci mengenai rencana kegiatan dan estimasi rencana pada setiap kegiatan termasuk juga dalam poin kriteria evaluasi ini. Pasal 1 Ayat (2) PMK Nomor 13 /PMK.02/2013 menyatakan bahwa BOPP sebagaimana dimaksud untuk kegiatan pada tahapan perencanaan, persiapan, pelaksanaan dan penyerahan hasil sudah termasuk untuk biaya administrasi dan pengelolaan. Sehingga dalam kriteria evaluasi ini DPPT Bendungan Karian Tahun 2016 tidak sesuai dengan ketentuan peraturan perundang-undangan.

8. Menguraikan rincian alokasi dana untuk sosialisasi

Dalam DPPT Bendungan Karian Tahun 2016 rincian alokasi dana untuk sosialisasi tidak diuraikan secara rinci mengenai rencana kegiatan dan estimasi rencana pada setiap kegiatan termasuk juga dalam poin kriteria evaluasi ini. Pasal 1 Ayat (2) PMK Nomor 13 /PMK.02/2013 menyatakan bahwa BOPP sebagaimana dimaksud untuk kegiatan pada tahapan perencanaan, persiapan, pelaksanaan dan penyerahan hasil sudah termasuk untuk sosialisasi. Sehingga dalam kriteria evaluasi ini DPPT Bendungan Karian Tahun 2016 tidak sesuai dengan ketentuan peraturan perundang-undangan.

\section{Kesesuaian Tahapan Pelaksanaan Pembangunan Bendungan}

DPPT Bendungan Karian Tahun 2016 tidak mencantumkan tahap- tahap atau proses rencana pembangunan Bendungan Karian baik tahap persiapan pembangunan, tahap perencanaan pembangunan, tahap persiapan pelaksaan konstruksi dan tahap pengisian awal waduk seperti yang diuraikan dalam PP Nomor 37 Tahun 2010 tentang Bendungan sehingga dalam kriteria evaluasi yang ditetapkan tidak sesuai dan tidak dirincikan dengan jelas dalam isi DPPT Bendungan Karian Tahun 2016 sehingga pada poin- poin kriteria tersebut tidak sesuai dengan ketentuan peraturan perundang-undangan. Hasil evaluasi antara DPPT Bendungan Karian Tahun 2016 dengan UU Nomor 2 Tahun 2012 dan PP Nomor 37 Tahun 2010 disajikan dalam Tabel 3. dibawah ini. 
Tabel 3. Hasil Evaluasi DPPT Bendungan Karian Tahun 2016 dengan Kriteria yang Ditetapkan

\begin{tabular}{|c|c|c|}
\hline No. & Kriteria Evaluasi & $\begin{array}{c}\text { Kesesuaian } \\
\text { dengan } \\
\text { Peraturan }\end{array}$ \\
\hline 1 & Maksud rencana pembangunan Bendungan Karian secara detail & Sesuai \\
\hline 2 & Tujuan rencana pembangunan Bendungan Karian secara detail & Tidak Sesuai \\
\hline 3 & Kesesuaian dengan RTRW Nasional & Sesuai \\
\hline 4 & Kesesuaian dengan RTRW Provinsi Banten & Sesuai \\
\hline 5 & Kesesuaian dengan RTRW Kabupaten Lebak & Sesuai \\
\hline 6 & Rencana Pembangungan Jangka Menengah & Sesuai \\
\hline 7 & Rencana Strategis & Sesuai \\
\hline 8 & Rencana Kerja Pemerintah Instansi BBWSC-3 & Sesuai \\
\hline 9 & Kesesuaian letak obyek pengadaan tanah berupa Desa/ Kelurahan & Sesuai \\
\hline 10 & $\begin{array}{l}\text { Kesesuaian letak obyek pengadaan tanah berupa Kecamatan dan } \\
\text { Jumlahnya }\end{array}$ & \\
\hline$\hat{1} \hat{1}$ & Kesesuaian letak obyek pengadaan tanah di Kabupaten Lebak & Sesuai \\
\hline 12 & Kesesuaian luas tanah perkiraan yang dibutuhkan & Tidak Sesuai \\
\hline 13 & Menguraikan data awal penguasaan atas tanah & Tidak Sesuai \\
\hline 14 & Menguraikan data awal pemilikan atas tanah & Tidak Sesuai \\
\hline 15 & Kesesuaian jangka waktu pelaksanaan tahap perencanaan & Sesuai \\
\hline 16 & Kesesuaian jangka waktu pelaksanaan tahap persiapan & Tidak Sesuai \\
\hline 17 & Kesesuaian jangka waktu tahap pelaksanaan & Tidak Sesuai \\
\hline 18 & Kesesuaian jangka waktu penyerahan hasil & Tidak Sesuai \\
\hline 19 & Kesesuaian perkiraan jangka waktu pembangunan & Tidak Sesuai \\
\hline 20 & Kesesuaian perkiraan nilai Ganti Kerugian tanah & Tidak Sesuai \\
\hline 21 & $\begin{array}{l}\text { Kesesuaian perkiraan nilai ruang, bangunan, tanaman, benda yang } \\
\text { berkaitan dengan tanah. }\end{array}$ & Tidak Sesuai \\
\hline 22 & Kesesuaian perkiraan nilai kerugian lain yang dapat dinilai & Tidak Sesuai \\
\hline 23 & Menguraikan besaran dana pengadaan tanah & Sesuai \\
\hline 24 & Menguraikan sumber dana pengadaan tanah & Sesuai \\
\hline 25 & Menguraikan rincian alokasi dana untuk perencanaan & Tidak Sesuai \\
\hline 26 & Menguraikan rincian alokasi dana untuk persiapan & Tidak Sesuai \\
\hline 27 & Menguraikan rincian alokasi dana untuk pelaksanaan & Tidak Sesuai \\
\hline 28 & Menguraikan rincian alokasi dana untuk penyerahan hasil & Tidak Sesuai \\
\hline $\begin{array}{l}29 \\
30\end{array}$ & $\begin{array}{l}\text { Menguraikan rincian alokasi dana untuk administrasi dan pengelolaan } \\
\text { Menguraikan rincian alokasi dana untuk sosialisasi }\end{array}$ & $\begin{array}{l}\text { Tidak Sesuai } \\
\text { Tidak Sesuai }\end{array}$ \\
\hline 31 & Menguraikan hasil survei sosial ekonomi & Tidak Sesuai \\
\hline 32 & Menguraikan kelayakan lokasi & Tidak Sesuai \\
\hline 33 & Menguraikan analisis biaya dan manfaat pembangunan bagi & Tidak Sesuai \\
\hline 34 & Menguraikan perkiraan nilai tanah & Tidak Sesuai \\
\hline 35 & Menguraikan analisis AMDAL & Tidak Sesuai \\
\hline 36 & DPPT ditetapkan oleh pimpinan instansi yg memerlukan tanah & Sesuai \\
\hline 37 & Perencanaan melibatkan pengampu dan pemangku kepentingan & Tidak Sesuai \\
\hline 38 & Menguraikan rencana pengelolaan SDA pada wilayah sungai dg & Tidak Sesuai \\
\hline 39 & Memuat kondisi SDA \& rencana tata ruang untuk pembangunan & Tidak Sesuai \\
\hline 40 & Memuat izin penggunaan SDA sesuai kewenangannya paling & Tidak Sesuai \\
\hline 41 & Memuat identitas pembangun bendungan & Tidak Sesuai \\
\hline 42 & Memuat rekomendasi teknis dari Unit Pelaksana Teknis yang membidangi & Tidak Sesuai \\
\hline 43 & Memuat studi kelayakan dan dokumen pengelolaan lingkungan hidup & \\
\hline
\end{tabular}


Menguraikan analisis kondisi topografi berupa rencana tapak bendungan,

46 Menguraikan analisis geologi

47 Menguraikan analisis hidrologi daerah tangkapan air

48 Menguraikan analisis kependudukan di daerah waduk dan bendungan

49 Menguraikan analisis sosial, ekonomi dan penerima manfaat bendungan

50 Menguraikan analisis kelayakan teknis, ekonomis, umur layana

51 Menguraikan rencana bendungan yang paling layak dipilih dan

52 Memuat gambar teknis rencana bendungan, bangunan

53 Memuat nota desain, kriteria dan perhitungan gambar teknis

54 Memuat spesifikasi teknis untuk mencapai kualitas yang disyaratkan

Tidak Sesuai

Tidak Sesuai

Tidak Sesuai

Tidak Sesuai

$\mathrm{n}$

Memuat metoda pelaksanaan, cara pengelakan sungai dan

56 Memuat rencana anggaran biaya pelaksanaan konstruksi bendungan

57 Memuat lokasi tanah yang diperlukan

58 Memuat peta dan luasan tanah

59 Memuat status dan kondisi tanah

60 Memuat rencana pembiayaan

61 Dilengkapi dengan studi pemukiman kembali (untuk permukiman)

62 Dokumen permohonan izin konstruksi

63 Dokumen desain yng telah disetujui, studi pengadaan tanah dan

64 Dilakukan sesuai hasil studi pengadaan tanah

65 Dilakukan sesuai ketentuan peraturan perundang-undangan

66 Mengutamakan teknologi

67 Memanfaatkan sumber daya lokal

68 Menguraikan permohonan pengisian awal waduk

69 Pembentukan unit pengelola bendungan

70 Laporan akhir pelaksanaan konstruksi

71 Laporan penyiapan pelaksanaan daerah genangan waduk

72 Rencana pengelolaan bendungan

73 Rencana tindak darurat

Tidak Sesuai

Tidak Sesuai

Tidak Sesuai

Tidak Sesuai

Tidak Sesuai

Tidak Sesuai

Tidak Sesuai

Tidak Sesuai

Tidak Sesuai

Tidak Sesuai

Tidak Sesuai

Tidak Sesuai

Tidak Sesuai

Tidak Sesuai

Tidak Sesuai

Tidak Sesuai

Tidak Sesuai

Tidak Sesuai

Tidak Sesuai

Tidak Sesuai

\section{Kesimpulan}

Dari penelitian ini didapatkan hasil sebagai berikut:

1. Didapatkan 73 Kriteria ideal dari UU Nomor 2 Tahun 2012 tentang Pengadaan Tanah Bagi Pembangunan Untuk Kepentingan Umum dengan aturan pelaksanaanya dan PP Nomor 37 Tahun 2010 tentang Bendungan sebagai bahan evaluasi DPPT Bendungan Karian Tahun 2016;

2. Hasil evaluasi kesesuaian antara DPPT Bendungan Karian Tahun 2016 dengan peraturan perundang-undangan dalam kegiatan pengadaan tanah dan Bendungan yang ditetapkan, dihasilkan 14 kriteria $(19,2 \%)$ sesuai dan 59 kriteria $(80,8 \%)$ tidak sesuai dari total 73 kriteria yang ditetapkan. Kemunduran penyelesaian pengadaan tanah Bendungan Karian salah satunya diakibatkan karena 59 kriteria DPPT Bendungan Karian Tahun 2016 tidak sesuai dengan peraturan perundang-undangan. Poin yang menyebabkan ketidaksesuaian itu antara lain: Gambaran Umum Status Tanah, Perkiraan Waktu Pelaksanaan Pengadaan Tanah, Perkiraan Waktu Pelaksanaan Pembangunan; Perkiraan Nilai Tanah, Rencana Penganggaran,Studi Kelayakan. Selain itu, disebabkan juga faktor pendanaan, kurangnya SDM pelaksana pengadaaan tanah, ritme 
kerja lintas instansi dan penyusunan rencana kerja yang tidak optimal, dan adanya pandemi korona pada tahun 2019- 2020.

\section{E. Rekomendasi}

a. Perlu disusun petunjuk teknis penyusunan Dokumen Perencanaan Pengadaan Tanah untuk mengatur secara rinci mengenai Dokumen Perencanaan Pengadaan Tanah;

b. Dalam penyusunan DPPT, instansi yang memerlukan tanah perlu melibatkan

c. lembaga pertanahan dan instansi terkait lainnya;

d. Dalam melakukan penyusunan DPPT Instansi yang memerlukan tanah (BBWSC-3) harus mempertimbangkan kriteria ideal DPPT seperti yang tercantum dalam UU Nomor 2 Tahun 2012 dan PP 37 Tahun 2010;

e. Perlu dilakukan penelitian lebih lanjut mengenai evaluasi DPPT Bendungan Karian Tahun 2016 dengan hasil penyelesaian pelaksanaan pengadaan tanah Bendungan Karian di Kabupaten Lebak.

\section{Daftar Pustaka}

Anonim, (2018). Pembangunan Waduk Karian Pembebasan Lahan Baru Capai 40\% 2018, Kabar Banten, 14 September 2018.

Dewi, N.L.G.M.P., \& Salim, M.N. (2020). Berakhir di Temon: Perdebatan Panjang Pengadaan Tanah untuk [New] Yogyakarta International Airport (YIA). STPN Press: Yogyakarta.

Hidayat, N. (2016). Pembangunan Bendungan Karian Kabupaten Lebak Provinsi Banten, Buletin Komite Nasional Indonesia untuk Bendungan Besar, No. 59-60 TH.XIX Kwartal I/II/III-2016,2016 ISSN:1829-636X.

Komite Percepatan Penyediaan Infrastruktur Prioritas (2019) Proyek Strategi Nasional: 2019 dilihat pada 20 Januari 2020, https://kppip.go.id/proyekstrategis-nasional/p-proyek-bendungan-dan-jaringanirigasi/bendungan-karian/

Moloeng, L.J. (2014). Metodelogi Penelitian Kualitatif, Bandung, Remaja.

Nugroho, A., Budhiawan, H., Sembiring, J., Mujiburohman, D.A., Utami, W. \& Dewi, A.R., (2018). Multipurpose Cadastre Pengadaan Tanah Dan Legalisasi Aset, Penerbit STPN Press, Yogyakarta.

Sitorus, O., \& Limbong, D. (2004). Pengadaan Tanah Untuk Kepentingan Umum, Yogyakarta, Mitra Kebijakan Tanah Indonesia.

Sugiyono. (2019). Metode Penelitian Kuantitatif, Kualitatif Dan R\&D. Bandung, Alfabeta.

Sumardjono, M.S.W. (2015). Dinamika Pengaturan Pengadaan Tanah Di Indonesia: Dari Keputusan Presiden Sampai Undang-Undang. Yogyakarta, Gadjah Mada University Press.

Yunus, H.S., (2016). Metodologi Penelitian Wilayah Kontemporer, Cetakan Kedua Yogyakarta, Pustaka Pelajar. 


\section{Peraturan-Peraturan}

Undang-undang Republik Indonesia Nomor 5 Tahun 1960 tentang Peraturan Dasar Pokok-Pokok Agraria.

Undang-Undang Republik Indonesia Nomor 26 Tahun 2007 tentang Penataan Ruang. Undang-Undang Nomor 32 Tahun 2009 tentang Perlindungan dan Pengelolaan Lingkungan Hidup.

Undang-undang Republik Indonesia Nomor 2 Tahun 2012 tentang Pengadaan

Tanah Untuk Kepentingan Umum.

Peraturan Pemerintah Nomor 37 Tahun 2010 Tentang Bendungan.

Peraturan Presiden Republik Indonesia Nomor 71 Tahun 2012 tentang Penyelenggaraan Pengadaan Tanah Bagi Pembangunan Untuk Kepentingan Umum.

Peraturan Presiden Republik Indonesia Nomor 40 Tahun 2014 tentang Perubahan Atas Perpres Nomor 71 Tahun 2012.

Peraturan Presiden Nomor 75 Tahun 2014 tentang Percepatan Penyediaan Infrastruktur Prioritas.

Peraturan Presiden Republik Indonesia Nomor 99 Tahun 2014 tentang Perubahan Kedua Atas Perpres Nomor 71 Tahun 2012.

Peraturan Presiden Republik Indonesia Nomor 30 Tahun 2015 tentang Perubahan Ketiga Atas Perpres Nomor 71 Tahun 2012.

Peraturan Presiden Republik Indonesia Nomor 148 Tahun 2015 tentang Perubahan Keempat Atas Perpres Nomor 71 Tahun 2012.

Peraturan Presiden Nomor 3 Tahun 2016 tentang Percepatan Pelaksanaan Proyek Strategis Nasional.

Peraturan Presiden Nomor 122 Tahun 2016 tentang perubahan atas Peraturan

Presiden Nomor 75 Tahun 2014 tentang Percepatan Penyediaan Infrastruktur Prioritas.

Peraturan Presiden Nomor 58 Tahun 2017 tentang Perubahan atas Peraturan Presiden Nomor 3 Tahun 2016 tentang Percepatan Pelaksanaan Proyek Strategis Nasional.

Peraturan Presiden Nomor 56 Tahun 2018 tentang Perubahan Kedua atas Peraturan Presiden Nomor 3 Tahun 2016 tentang Percepatan Pelaksanaan Proyek Strategis Nasional.

Peraturan Menteri Keuangan Nomor 10./pmk.02/2016 tentang Perubahan Atas Peraturan Menteri Keuangan Nomor 13 /PMK.02/2013 tentang Biaya Operasional dan Biaya Pendukung Penyelenggaraan Pengadaan Tanah Bagi Pembangunan Untuk Kepentingan Umum yang Bersumber dari Anggaran Pendapatan dan Belanja Negara.

Peraturan Daerah Kabupaten Lebak Nomor 2 Tahun 2014 tentang Rencana Tata Ruang Wilayah Kabupaten Lebak Tahun 2014-2034.

Peraturan Daerah Provinsi Banten Nomor 2 Tahun 2011 tentang Rencana Tata Ruang Wilayah Provinsi Banten Tahun 2010-2030. 
Keputusan Gubernur Banten Nomor: 598/ Kep.82-Huk/2016 Tanggal 4 Februari 2016 Tentang Pembaharuan Penetapan Lokasi Pengadaan Tanah Untuk Pembangunan

Bendungan Karian seluas $\pm 1.362,29 \mathrm{Ha}$ yang terletak di wilayah Desa Pasirtanjung Kecamatan Rangkasbitung, Desa Sindangmulya Kecamatan Maja, Desa Sajira, Sukajaya, Pajagan, Mekarsari, Calungbungur, Bungurmekar, Sukarame, Sindangsari Kecamatan Sajira dan Desa Tambak Kecamatan Cimarga. 